\title{
La actitud de los estudiantes del programa de iniciativa empresarial de la Universidad de Puerto Rico, Recinto de Río Piedras, hacia las franquicias
}

\section{Carliana Carrasquillo Cintrón}

Síntesis

El estudio tuvo como objetivo principal conocer la actitud de los estudiantes del Programa Iniciativa Empresarial hacia las franquicias como medio para establecer un negocio. El segundo objetivo fue medir si los estudiantes estaban dispuestos a establecer una franquicia.

Los resultados de la investigación demostraron que los estudiantes del Programa Iniciativa Empresarial tenían poco conocimiento sobre el tema de estudio. En cuanto a la actitud, encontramos que un 52\% de los participantes tenían valores en sus sumatorias próximos a 48 (punto divisorio entre lo que sería una actitud positiva y una negativa). La investigadora consideró que estas sumatorias no reflejaban una actitud decididamente favorable hacia las franquicias. Los valores mayores de 48, cinco personas cuya sumatoria estaban entre 60 y 63, tampoco se consideraron con una orientación contundentemente positiva hacia las franquicias. Por lo tanto, la investigadora no cree prudente concluir que la actitud de la mayoría de los entrevistados es positiva, aunque halla una inclinación a favorecer las franquicias.

Al medir la intención de los estudiantes hacia establecer una franquicia, ésta se reagrupó en dos grupos, intención en el ámbito gerencial e intención empresarial. 
La intención en el ámbito gerencial reflejó indecisión, debido a que los encuestados no asumieron una inclinación positiva ni negativa. No obstante, la intención de establecer una franquicia como gestión empresarial fue positiva.

\section{Análisis sobre la implantación y funcionamiento de los Planes de Retiro 401 (K) en Puerto Rico}

\section{Sandra I. Damiani Rivera}

\section{Síntesis}

A nivel mundial las compañías presentan una inquietud cada vez mayor por proveer a los empleados de planes de retiro, especialmente el plan 401 (k). Esta demanda responde no sólo a la reducción de costos que ello implica, sino al cumplimiento de varias necesidades laborales del patrono como recompensa a los empleados para retenerlos e incentivarlos. Puerto Rico no está ajeno a esta corriente, y la tendencia del mercado puertorriqueño ha ido en aumento en la implantación de estos planes.

Para el desarrollo de los planes de retiro es necesario tener presente ciertas peculiaridades que caracterizan su implantación. Además, existen disposiciones de la ley federal y del Código de Rentas Internas Estatal y Federal que deben cumplirse a cabalidad para garantizar su eficiencia. Esta situación guió la realización de un estudio que enfatizó no sólo la perspectiva teórica-conceptual de los planes de retiro 401 (k), sino su implantación y desarrollo en Puerto Rico.

Con este propósito principal se llevó a cabo una encuesta a una muestra de compañías puertorriqueñas con mayor ingreso en el año 1999. Para la recopilación de los datos se administró un cuestionario que recogía datos del perfil de las empresas, nivel de participación de los empleados en el plan 401 (k) y las motivaciones y desarrollo del plan por las compañías encuestadas. Se recibió el 35.6\% de los cuestionarios enviados, muestra representativa de la pobla- ción bajo estudio que permitió el análisis apropiado. Con este fin se obtuvieron distribuciones porcentuales de todas las respuestas del cuestionario con sus respectivas medidas de tendencia central.

El análisis de los datos reveló que es necesario crear conciencia de los beneficios que implica el plan para los empleados, ya que sólo una tercera parte de las compañías provee el plan. Sin embargo, las compañías que lo ofrecían reflejaron una participación activa de los empleados. Además, las compañías ofrecían orientación adecuada y variada a sus empleados. La mayoría de las compañías son conscientes de la importancia y la necesidad de los planes de retiro y muestran preocupación por el empleado y su bienestar. Otro aspecto sobresaliente en el análisis se observó en el pareo de las aportaciones lo que reflejó que los patronos tienen interés en apoyar el retiro de sus empleados. También se observó que la mayoría de las compañías ofrecía diversas alternativas de inversión, tales como acciones de alta capitalización y crecimiento, bonos domésticos e internacionales, entre otras alternativas.

Este estudio permitió presentar un cuadro del funcionamiento de estos planes en una muestra de compañías puertorriqueñas. Sin embargo, se recomienda un estudio más amplio y abarcador. De esta forma se tendría la herramienta necesaria para un mejor diseño y desarrollo de estos planes y una campaña de orientación que garantice el éxito de los mismos.

\section{Estudio exploratorio: El efecto de la música en el placer de los clientes mientras esperan por la prestación de un servicio dental}

\section{Dinorah D. Talavera Orshini}

Síntesis

La investigación pretendió identificar el efecto de la música en el placer de los clientes durante la espera por la prestación de un servicio dental. El escenario del estudio fue la oficina del periodoncista 
Dr. Carlos Quiñones localizada en la Torre de Plaza las Américas, Hato Rey, Puerto Rico. El objetivo se midió mediante un "quasiexperimento" utilizando como herramienta un cuestionario. Este experimento constó de dos tratamientos, con música y sin música. La muestra fue de 82 clientes, 39 clientes del grupo sin música y 43 del grupo con música.

Se evaluaron tres hipótesis relacionadas al efecto de la música en el placer y la tensión de los clientes mientras esperan, y la correlación entre el placer y la tensión. Los resultados demostraron que la música instrumental no crea un efecto significativo en el placer ni en la tensión de los clientes de este periodoncista. También se encontró que el cambio en tensión del cliente mientras espera por el servicio no se relaciona con el placer que experimentó en la oficina dental.

\section{Client Consideration in Designing Senior Housing: An In-Depth Exploration}

\section{Heidi Ann Sánchez Benitez}

\section{Abstract}

We are growing older fast and this means solid growth for businesses catering to the seniors market. The researcher embarked upon this investigation because she saw the lack of senior retirement community projects in Puerto Rico as an excellent business opportunity for real estate developers. An opportunity existed for the development of such a community aimed at the affluent senior within the master planned resort property at Palmas del Mar, located in Humacao, PR. Thus, the study focused on exploring some motivational factors of the target market and on defining some desirable amenities and architectural features that may prove essential to the success of a luxury retirement community in Puerto Rico.
The researcher obtained the data through thirteen in depth personal interviews conducted with senior citizens aged 65 or better with a monthly gross income of over $\$ 3,000$. The sessions included the presentation of a retirement community concept with the intention of ensuing reactions, the identification of desirable amenities, and any requisite architectural features.

The researcher was able to conclude that, given the lack of luxury senior retirement communities in Puerto Rico, many elders have a negative perception of them and associate the idea with nursing homes.

Because of this negative connotation, and the cultural taboo that leads the family to care for their aging, elders refuse to actively consider their future health and housing needs, assuming they will remain at home until their death. Nonetheless, through the interview process, the researcher was able to generate a list of desirable amenities and architectural requirements ranked in order of importance. The most important desirable amenities are meal, medical and housecleaning services, family accessibility, good administration, and social interactions. Specifically, they require dining alternatives, nursing and security services, transportation, visitor parking facilities, and activity rooms for a variety of entertainment purposes. Elders are less interested in golf courses, tennis courts, beaches and gymnasium facilities, something that poses a problem for the Palmas del Mar project, due to its emphasis on exactly that active lifestyle. Elders also prefer an urban location close to family and friends, another negative element in the Palmas del Mar project due to its location in the southeastern part of the island, far away from Metro San Juan, where the target market segment is concentrated.

These conclusions suggest the need to evaluate any senior retirement community project in Puerto Rico with a focus on educating the potential target market through individual product promotion as well as through industry wide image building.

The findings also suggest that family is an influencing factor in the decision to move to senior housing and thus the developer must market to them as well. 